\title{
DIDACTIC GAME AS AN ADVANCED METHOD OF COMMUNICATIVE COMPETENCE FORMATION IN FUTURE SPECIALISTS IN DOCUMENTATION AND INFORMATION SERVICES
}

\author{
Natalia Tkachova \\ H.S. Skovroda Kharkiv National Pedagogical University, Kharkiv, Ukraine \\ tkachna2015@ukr.net \\ Oksana Tur \\ Poltava National Technical Yuri Kondratyuk University, Poltava, Ukraine \\ 1.oksanetur@gmail.com
}

\begin{abstract}
The article states that the formation of communicative competence in future specialists in documentation and information activities alongside with professional competence is a measure of educational quality. The skills and abilities constituting communicative competence of a specialist in documentation are listed, including the ability to participate in collective decisions, taking up responsibility, resolving conflicts without violence, expressing tolerance and respect for people of other cultures, languages and religions; living in a multicultural society and others. The main characteristics of didactic games have been outlined (design, roles and responsibilities, common goals, cooperation, teamwork, the presence of competition elements). The article discusses the basic requirements for didactic games which include joint activities and mutual responsibility of participants; contextual use of results; developing creative thinking; involving participants into the dialogue and others. The author discusses the results of implementing didactic games with students of the "Record Keeping", "Documentation", "Information and Analytical Activity" specialities. Qualitative indicators of positive changes have been revealed in the levels of students' communicative competence after using a business game as the basic didactic method. Conclusions state the importance of implementing a didactic game in the communicative competence formation in future specialists in documentation and information services.
\end{abstract}

Keywords: communicative competence; communication; method; didactic game; documentation; record keeping; information and analytical activity.

\section{Introduction}

Modern socio-political, economic and cultural transformations in society enhance the role of information processes in all spheres of public activity, causing a continuous growth of information and documentary support. It requires training of highly skilled and competitive professionals, able to provide qualitative processing of documentary information.

An indicator of educational quality in the field of documentation and information activities alongside with professional competence is the communicative competence, which includes the ability and willingness of the employee to participate in collective decisions; to take up responsibility; to resolve conflicts without violence; to maintain and improve democratic institutions; to express tolerance and respect for people of other cultures, languages and religions; to live in a multicultural society and to recognise the difference between people; to efficiently use oral and written communications; to adapt to new conditions (new people, new language means, new modes of action); to learn throughout the whole of one's life; to acquire new knowledge and to realise one's personal potential; to treat information critically; to combine social, collective and individual interests; to stand against racial, ethnic, age discrimination; to protect the interests of the state, etc. (Maksymenko \& Zabrotskyi, 2005; Savichev, 2010; Skvortsova \& Vtornikova, 2013; Semenog, 2013).

Various issues of communicative competence formation have been the subject of a comprehensive study in the works of many scholars. Of particular importance in training highly-qualified professionals are the interactive teaching methods, including different types of didactic games (Master, 2005; Yelagina, 2014; Zabrotskyi, 2005; Maksymenko, 2005; Kulish, 2003; Savichev, 2010; Semenog, 2013; Skvortsova, 2013; Vtornikova, 2013; Ternavska, 2013; Fedchishin, 2014; Kolomiets \& Konoplenko, 2015; Chubar, 2016).

The purpose of the article is to analyse a didactic game as an advanced method of communicative competence formation in future specialists in documentation and information activities. Thus, we aim to suggest didactic games that can be used in teaching "Record Keeping", "Documentation", "Information and Analytical Activity".

In our study, we define the communicative competence of future professionals in documentation and information activities as an integrated personal formation, a generalised ability of the individual to solve different problems (Skvortsova \& Vtornikova, 2013, p. 22). It should be noted, that communicative 
competence is formed in the social environment in the process of acquiring social and communicative experience.

\section{Methods}

The choice of methods to form and develop communicative competence depends on the training objectives, the content of learning and the professional motivation of future specialists (Savichev, 2010, p. 78). The undeniable fact is that raising the level of communicative competence in future specialists of documentation and information activities in the course of their training is promoted by the efficient combination of traditional (lectures, practical seminars) and unconventional (trainings, roundtable discussions, debates, educational games, etc.) methods of teaching.

Among the most efficient non-traditional methods of communicative competence formation in the process of teaching the disciplines "Record Keeping", "Documentation", "Information and Analytical Activities", we emphasise the importance of didactic games. We consider a game as a specially organised activity of its participants, enabling the implementation of theoretical knowledge in active communicative interaction, as well as improving habits, development of certain skills, helping to enhance students' creativity and problem-solving skills. Games are multi-purpose activities (Kulish, 2003). For example, the use of business games is aimed at training students to take decisions on different work-related issues, to make presentations, analytical reviews, etc. Research games are related to developing new concepts, analysing problems and predicting consequences of implementing innovations. Educational games promote the efficient acquisition of certain knowledge, develop and reinforce communication skills. Qualifying games are conducted to determine the level of competence, qualification of future professionals. Organisational activity games are aimed at team-building. Reflexive games are aimed at reflexive analysis of human relations, group and intergroup business interaction based on the principles of cooperation. Didactic games develop reproductive and creative thinking, adaptive, learning and self-improvement skills. According to Yelahina (2014) and Fedchishin (2014), role-play should be implemented in education process as an effective method of communicative competence formation in future professionals.

Among the main characteristics of the didactic games presented in the scientific literature (Kulish, 2003; Yelagina, 2014), we outline the following: modeling situations in the sphere of documentation and information services; distribution of roles between the participants of the game; interaction between participants, performing different roles; common goals for the whole team; collective decision-making; presence of the competition elements, polarity of the participant's interests.

For the purpose of communicative competence formation by means of didactic games, we distributed future documentation specialists of Poltava National Technical Yuri Kondratyuk University into 2 groups: the control group (CG) (40 students) and the experimental group (EG) (42 students).

The specially developed questionnaire aimed at assessing students' readiness to communicate with other people efficiently, determining the level of confidence in communication. Students were offered 10 pairs of contradictory statements, among which they had to choose the most relevant ones according to the scale from 4 to 1.

An important component of communicative competence is the ability to listen carefully. Listening ability was assessed by means of a questionnaire, specially designed by authors, suggesting 25 situations to the respondents. The students had to indicate whether the situations caused irritation or displeasure (they answered "yes" or "no"). The results were grouped into three levels - high, medium and low. After obtaining the results (they did not differ significantly in two groups), we conducted professional training using didactic games in EG.

As an example, we provide the following didactic games developed on the basis of the ideas of Maksymenko \& Zabrotskyi (2005), which were used in the professional training of future specialists in documentation and information services, ("Basics of Document Management", "Documentation", "Information and Analytical Activities") during the period from 2013 to 2016.

\section{"The training meeting"}

The goal of the game on the formation of communicative competence is to promote interactive communicative interaction, develop organisational skills and the ability to assess the communicative situation adequately, foster tolerance and empathy.

Preparatory stage. We share responsibilities among participants (chairman, secretary, and documentation scientists). There also should be the referees who will assess the players' performance. 
The main stage.

1) The chairman delivers the opening speech indicating the purpose and objectives of the meeting, emphasises their practical value, reports on the audience combination, suggests electing the Secretary to maintain the relevant documentation, and announces the procedure and the allotted time.

2) Researchers deliver their reports in favour of their own concepts on the document according to the agenda, answer the questions to enhance and supplement information, belief in the reliability of the data, etc. (sometimes debates arise).

Final stage. It includes approving the decision, brainstorming of all reports, evaluating the teamwork.

"CAREO (Consultant. Arbiter. Reviewer. Erudite. Opponent)"

Preparatory stage. Teacher forms main groups of participants: erudites, opponents, reviewers, organisers, consultants, arbiters. Group of erudites must prepare the main message on the analysed problem. Teacher gives them the necessary assistance in drafting the plan, selection and summarising of information. Group of opponents must prepare for discussions with erudites. It includes deep analysis, the formation of their own attitude to the problem under consideration, preparing problematic questions. The group of reviewers analyses the messages of erudites. They have to figure out the basic requirements for a review. The group of organisers provides a draft outcome which reveals the essence of basic concepts on the subject classes and links between them (review, opinion, reference scheme of the information delivered, etc.). The group of consultants provides informational assistance and psychological support to the participants. The group of arbitrators reasonably estimates the work of each group.

The main stage.

1. The teacher reports the rules and regulations of performances of each group. 2. The first student reports and the opponents ask questions. 3. If the answer is incomplete or incorrect, the teacher can ask consultants or opponents. 4. The reviewers analyse messages. 5. After discussing, the messages of other erudites are listened and analysed too. 6 . The organisers carefully listen to the reports making adjustments and additions to the final document and form summary document to provide the collective analysis. 7. During the game, the referees assess the performance of each group. The participants report on the results of a quantitative and qualitative evaluation.

Final stage. In the closing speech, the teacher dwells on characterising the scientific foundations of the conclusions made by the players. If it is necessary he/she makes adjustments to the outcome document. Simultaneously, the teacher analyses the features, organisation, and collective cognitive group activity.

\section{"Communicative interaction"}

The goal of the formation of communicative competence is to develop the ability to direct the communication process, to ask questions and give the correct, logical answers, evaluate the answers of other participants and own responses, develop empathy and reflection.

Preparatory stage. Students are divided into pairs and get tasks such as:

a) to model the communicative situation between the chief accountant of a private company and a consultant of a tax office. In the discussion you may use scientific and practical journals in accounting.

b) to model the discussion between researchers of documentation and future professionals of information activity regarding the professional literature that they have recently read.

The main stage. Two students discuss the problem, other students act as controllers. The conversation lasts 5-7 minutes. Speaking in pairs, students must adhere. Before expressing an opinion, they should repeat what another student has told. Repetition may begin with the words: "You say that ...", "Do you think ...", "You convince ...", "You notice ..." and others. Controllers should ensure that the rule is followed and they may interfere with the conversation if the performers forget to follow it.

Final stage. After the exercise is over, it is advisable to discuss the question "How did repeating of the the interlocutor's words influence the conversation?"

The process of using didactic games should meet certain requirements once formulated by Tharp (1989):

1) joint receptive and productive activity of teachers and students, aimed at achieving the ultimate goal, which is common responsibility of all the communication process participants;

2) assistance in mastering the educational material and ensuring continuous, targeted development of students at all stages of the teaching process;

3) contextual use of training outcome, i.e. application of experience obtained in specific life situations (as the dominant motive of the students' learning activities is mastering of future profession, it is advisable to choose the game situations reproducing the real professional ones);

4) developing critical thinking skills; 
5) involving the participants in the dialogue (the subjects proposed for discussion should be familiar to all students; situations should provoke interest, particularly having a problematic nature and different ways of solving) (p. 51-66).

\section{Results and Discussion}

The assessment of the results of students'readiness to communicate with other people efficiently, determination the level of confidence of future documentation experts in their communication abilities, showed that at the initial stage of the experiment, those who scored 30 or more points, i.e, having the high level of confidence, accounted for 14\% of EG-group students and 16\% of those in CG-group. They are initiators of relations, having active attitude to life, self-confident, erudite, competent in various fields of social activity, those who come into contact easily. $46 \%$ of students in EG and $44 \%$ in CG showed the low level with the total number of points not exceeding 20. These are the students who encounter certain communication problems, they have a lack of self-confidence, initiative, vocabulary, knowledge of language rules, non-verbal communication means, etc. Most respondents scored 21 and 29 points, being the indication of the medium level of confidence in their own communicative abilities. These students (they accounted for $40 \%$ in EG and the same amount in CG) can be initiators of communication but not always. After the experiment, the number of students with high levels of confidence in communication grew by $10 \%$ in EG and only by $4 \%$ in CG; the number of students with the medium level increased by $18 \%$ and $8 \%$ respectively. The number of students with low communication level reduced by $28 \%$ in EG, and by $12 \%$ in CG.

The changes occurred in the level of careful listening skills in students after implementing business games in the classroom. At the beginning of the experiment, $9 \%$ of the respondents in EG and $8 \%$ of those in CG had a high level of listening ability (typical for students who know how to listen; they focus on their partner's words and constantly follow their interlocutor's discourse, support an eye contact with the dialogue partner, capable of verbal and nonverbal demonstrating). The medium communication level was determined in $45 \%$ and $41 \%$ of students respectively (as a whole they are good partners in social interaction, but sometimes these people do not pay enough attention to their interlocutor).

The total of $46 \%$ and $51 \%$ of students had a low communication level (they are critical to statements, sometimes monopolise the conversation, do not always correctly understand the interlocutor's feelings, sometimes express their negative reaction to the communication partner's words).

At the end of the experiment, these indices were as follows: in the EG, high level of listening ability in communication was detected in $21 \%$ of students; the medium level was recorded in $59 \%$ of respondents, the low level occurred in $20 \%$ respectively. In the CG, the indices were as follows: high communication level was determined in $12 \%$, medium - in $49 \%$, low - in $39 \%$ of students.

The obtained results indicate that the EG students, who have participated in business games during professional training, compared to $\mathrm{CG}$ students, are better prepared for constructive communicative interaction, and therefore, have a higher level of communicative competence.

The need for involving didactic games into the educational process of a university is associated with psychological and pedagogical features, educational and didactic possibilities, as well as the students' interest in it. According to Ternavska (2013), the method of business and role-playing games "...reflects social and subject contexts of future professional career and highlights the developmental nature of the education process at the university" (p. 330). The function of a teacher in didactic games is to help in developing students' general educational skills, as well as special skills, necessary for mastering a certain academic discipline. According to Kulish (2003), a game creates such an atmosphere during classes that improves students' health and mood, creates positive emotions and develops their self-confidence and the sense of responsibility, which improves the efficiency of teaching and learning (p.16).

\section{Conclusions}

We consider a didactic game as an effective method to form communicative competence of future professionals in documentation and information activities as their generalised ability to update their obtained knowledge and skills in standard and problematic communicative situations to deal efficiently with life and professional problems. The suggested didactic games encourage active communicative interaction, raise the ability to solve possible conflicts, develop organisational skills. These activities enhance tolerance, empathy and reflection, the ability to maintain dialogue, ask questions and give logical and correct answers.

The main component of the game, in our opinion, is the role taken by a certain player. The role is a set of social demands, expectations imposed on a person by the society. Role taking is performed on the cognitive, emotional, behavioural levels. It is realised through behavioural norms, tasks inherent to the role and its performance. 
The implemention of didactic games in the education process is characterised by psychological and pedagogical features, including teaching possibilities and students' interest in this method. We consider the main characteristics of the didactic games to be the following: modelling, roles distribution, interaction of participants with the elements of competition.

In our further study, we are going to analyse the features of an interactive lecture as an efficient method of forming communicative competence of future specialists in documentation and information services.

\section{References:}

Chubar, V. (2016). Vykorystannia interaktyvnykh tekhnologii u protsesi profilnogo tekhnologichnogo navchannia starshoklasnykiv [Interaxctive technologies used in the process of subject-oriented education of students]. Naukovi zapyski Kirovogradskogo derzhavnogo pedagogichnogo universytetu, 9 (3), 141-145

Fedchishin, N.O. (2014). Vykorystannia dydaktychnoi gry pry vyvchenni nimetskoi movy v umovakh universytetu [Didactic games applied in teaching Geman at the University]. Naukovi zapyski natsionalnogo universytetu "Ostrozka akademiia". Seriia: Psykhologiia i pedagogika, 26, 132-135.

Kulish, I.M. (2003). Didaktichna gra yak zasib aktivizatsii navchalnoi diialnjsti studentiv universitetu [Didactic game as a way of activating education activities of the university students]. Extended abstract of $\mathrm{PhD}$ thesis, Kyiv, Ukraine.

Kolomiets, S. S. \& Konoplenko, L. O. (2015). A model for teaching speaking English for Specific Purposes (information security) using business game. Advanced Education, 3, 58-63. http://dx.doi.org/10.20535/2410-8286.44209

Maksymenko, S. D. \& Zabrotskyi M. M. (2005). Tekhnologiia spilkuvannia (kommunikatyvna kompetentnist uchytelia: sutnist $i$ shlakhy formuvannia) [Communication technology (Communicative competence of the teacher: its essence and ways of formation)]. Kyiv, Ukraine: Glavnyk.

Master R.J. (2005). Communicating in your World. Ottava, Canada: Academic press Canada.

Savichev, S. S. (2010) Problema razvitiia kommunikativnoj kompetentnosti studentov vy'sshej shkoly' [Problem of developing communicative competence in the higher school students]. Izvestiya Samarskogo nauchnogo czentra rossijskoj akademii nauk. 12 (5), 78-80.

Semenog, O. (2013). Formuvannia kommunikatyvnoi kompetentnosti maibutnikh ekonomistiv: aksiologichnyi pidkhid [Formation of communicative competence in future economists: axiological approach]. Pedagogika vyshchoi ta serednoi shkoly. 38, 266-270.

Skvortsova, S.O. \& Vtornikova, Yu. S. (2013). Profesiino-kommunikatyvna kompetentnist uchytelia pochatkovykh klasiv [Professional and communicative competence of the elementary school teacher]. Odessa, Ukraine: Abrikos Kompani.

Ternavska, L.M. (2013). Zastosuvannia partysypatyvnykh metodiv u protsesi navchannia inozemnoi movy maibutnikh ekonomistiv [Participation methods applied in the process of teaching foreign languages to future economists]. Pedagogichni nauky: teoriia, istoriia, innovatsiini tekhnologii. 5(31), 327-332

Tharp, R.G. (1989). Culturally compatible education: A formula for designing effective class-rooms. In H.T.Trueba, G.Spindler \& L. Spindler, What do anthropologists have to say about dropouts? (pp. 51-66). New York, USA: The Palmer Press

Yelagina, N. I. (2014). Rolova gra yak aspect motyvatsii u vykladanni inozemnykh mov studentam-medykam [Role playing game as an aspect of motivation in teaching foreign languages to medical students]. Naukovi zapyski natsionalnogo universytetu "Ostrozka akademiia”. Seriia: Psykhologiia i pedagogika, 26, 66-69. 
